\title{
ПРІОРИТЕТИ МОВОЗНАВЧИХ ДОСЛІДЖЕНЬ ПРОФЕСОРА ОЛЕКСАНДРИ СЕРБЕНСЬКОЇ
}

\author{
Олена Кузнецова \\ Національний університет «Львівська політехніка» \\ вул. Степана Бандери, 12, 79013, Львів, Україна \\ e-mail: o.d.kuznetsova@gmail.com \\ https://orcid.org/0000-0002-9596-1386
}

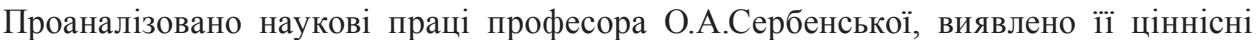
орієнтири: служіння своєму, українському; названо праці з пріоритетних розділів прикладного мовознавства: лексикографії, лінгвофранкознавства, соціолінгвістики, екології мови, культури мови, ономатології, фразеології, етимології, дериватології; розділів теоретиччної лінгвістики: філософії мови, естетики мови, історії мови, компартивістики, лінгвофеноменології та інших; виявлено поєднання в одному дослідженні кількох розділів мовознавства, журналістикознавства та інших наук.

Ключові слова: українське теоретичне, прикладне мовознавство, культура української мови, екологія української мови, термінологія, фразеологія, дериватологія, мовне франкознавство, нові розділи українського мовознавства.

Постановка проблеми. У мовознавстві, як і в будь-якій науці, провідне значення вченого - в опорі на моральні ціннісні орієнтири, затребуваності результатів досліджень з пріоритетних наукових розділів, їх суспільного, державного значення, що зумовлює актуальність порушеної теми статті.

Щоб далі розвивати українське мовознавство, наукову школу української медіалінгвістики професора Олександри Антонівни Сербенської, треба визначити пріоритети їі досліджень, ціннісні орієнтири, традиційні й нові розділи українського мовознавства, що зумовлює прикладне значення порушеної проблеми.

Глибинне, осмислене усвідомлення вибору ціннісних орієнтирів у науці й неухильне їх дотримання для розвитку наукових ідей своїх Вчителів, щоденна праця під постійним самоконтролем є пріорітетами заслуженого професора Львівського національного університету, почесного академіка Академії наук вищої школи, професора Олександри Антонівни Сербенської.

Загадка і розгадка довголіття в науці вченого у вмінні розставити пріоритети в житті, науці, спираючись на «вічні» цінності. Знайти відповідь загадки пріоритетів визнаного науковця О.А.Сербенської - це розгадати загадку, встановити, образно кажучи, місце вченого на Олімпі наукової галузі, виявити розділи мовознавства, яким віддає перевагу.

(C) Кузнецова О., 2019 
Ціннісні домінанти багаторічних мовозначих наукових досліджень О.А.Сербенської - прості: досліджувати своє. Пріорітетом шановного професора у всіх їі дослідженнях є служіння рідному народові, Україні, відстоювання права людини на рідну, державну, не засмічену українську мову, сприяти дотриманню норм української літературної мови, очищенню української мови, від суржика в усному та мас-медійному мовленні.

Найпершими пріоритетами відомого мовознавця в Україні О.А.Сербенської є любов до своєї Української держави, українського народу, української культури, української освіти. Про це свідчать численні наукові статті, монографії, інші наукові праці дослідниці. За багатолітню вірність пріоритетним орієнтирам у наукових дослідженнях, обстоюванні й вдосконаленні української мови, за вагомий науковий внесок в науку, освіту, мовну й мовленнєву практику шанують О.А.Сербенську.

Пріоритети мовознавчих досліджень науковця О.А.Сербенської - це комплекс найзатребуваніших мовознавчих розділів, напрямів суспільно-значимих досліджень, виконаних науково-дослідницьких тем, яким професор приділяє найчастіше і найбільше уваги, що зумовило об’єкт нашого дослідження - опубліковані наукові праці Олександри Антонівни 1958-2017 років.

Аналіз останніх досліджень. У Вступі до збірника статей «Олександра Сербенська» з серії «Заслужені професори Львівського національного університету імені Івана Франка» (Львів, 2014 р.) названо коло її інтересів: культура української мови (це розділ українське мовознавство); художньо-публіцистичний світ Івана Франка (розділ лінгвофранкознавство), мовні проблеми формування національного інформаційного простору України (розділ - соціолінгвістика), роль української мови в національній безпеці держави (розділ - соціолінгвістика); унормування сучасної української мови (розділ - культура української мови), боротьба з засиллям суржика (новий розділ - екологія української мови) [1;с.3]. У своїй статті згаданої книги завідувач кафедри журналістики Українського католицького університету В.В.Бабенко зазначає: «Як талановита дослідниця О.А.Сербенська надбала значну спадщину у різних напрямах наукових знань: термінології, перекладознавстві, франкознавстві, мовознавстві, журналістиці [1, с. 5]. Професор Дніпропетровського університету В.Д.Буряк писав про Олександру Антонівну: «Вона створила наукову парадигму екології мови, екології мовної комунікації [1; с.17] (це розділи мовознавства - екологія української мови, екологія української мовної комунікації). Професор Київського університету імені Тараса Шевченка О.Д.Понамарів називає традиційні розділи мовознавства: «У колі наукових зацікавлень пані Сербенської - лексикологія, термінологія, стилістика, діялектологія та инші сфери української мови, але найбільше уваги приділяє пані професор питанням культури української мови»[ 1, с.43].

Як показав аналіз статей згаданого збірника про проф. О.А.Сербенську українські мовознавці називають не більше п'яти розділів мовознавства, з якими пов'язані дослідження дослідниці. В той час як сучасне українське мовознавство нараховує десятки розділів. Лише з заголовків праць зі списку публікацій О.А.Сербенської згаданої книги, помітно, що їх є в рази більше.

Висунемо робочу гіпотезу: праці професора О.А.Сербенської порушують проблеми більшості розділів українського мовознавства. Означимо мету дослідження: виявити у наукових працях О.А.Сербенської пріоритети їі мовознавчих досліджень 3 теоретичних і прикладних розділів мовознавства, для чого виконаємо такі завдан- 
ня: осмислити наукові статті, монографії, науково-дослідницькі теми, книги авторки, визначити, до якого розділу, підрозділу мовознавства вони належать, для цього виявити в наукових працях основні ознаки розділів, диференціювати останні на теоретичні й нові, показати яким із них найбільше приділяє увагу дослідниця, показати охоплення багатьох розділів мовознавства, пріоритетне суспільне значення їі досліджень для Української держави, що й буде визначенням наукових мовознавчих пріорітетів шановного професора.

Результати. Переважно об'єктом мовознавчих студій О.А.Сербенської є українська мова. В кількох статтях - українська, польська, або українська, російська мови. До прикладу доповіді на конференціях «Основні тенденції розвитку сучасної східнослов’янської юридичної термінології» (1974р.), стаття «Мовні взаємини у процесі розвитку юридичної термінології російської та української мов» (1979 р.). «Взаємини української та польської мови у процесі формування адміністративно-юридичної лексики другої половини ХІХ ст.» (1982р.); «Рудименти російського канцеляриту в сучасній українській мові» (1998р.), «Із спостереження над мовою польської версії повного перекладу поезій Тараса Шевченка» (2014р.) та інші. Тому справедливо називати шановну О.А.Сербенську україністом, славістом.

В теоретичному мовознавстві О.А.Сербенська обрала порівняльно-історичний розділ, порівняльну компаративістику, порівнюючи історичний розвиток української мови, залежність української від російської, польської мов. До прикладу стаття «Значення російської мови для формування українських складних і складених юридичних термінів» (1964р.); доповіді «Основні тенденції розвитку східнослов`янської юридичної термінології» (1974р.), «Взаємини української та польської мов у процесі формування адміністративно-юридичної лексики другої половини XIX ст.» (1982р). Водночас названі статті О.А.Сербенської містять порівняльний аналіз української і споріднених, східнослов'янських мов, що дає підстави віднести їх також до розділу зіставного мовознавства.

С в О.А.Сербенської праці з теоретичних мовознавчих розділів: філософії української мови, статті з естетики української мови. До прикладу: «Мова преси як естетичний стереотип епохи» (2000р.). Найоб'ємніше проблеми філософії мови або лінгвофілософії розкриті в монографії «Мовний світ Івана Франка: статті, роздуми, матеріали» (2006 р.). Підрозділом філософії мови є феноменологія мови, якій професор присвятила кілька статей: «Феномен рідної мови в інтерпретації Івана Франка» (1997 р.), «Феномен усного мовлення» (2000р.), «Культурологія мовленого слова: звуковий лад мови як феномен національної культури» ( 1999 р.).

Не одну статтю написала О.А.Сербенська з концептології української мови, підрозділу філософії мови. До прикладу «Франкова концепція зв’язку мови і духовності» $(1990$ р.),

Чимало праць дослідниці належать до розділу українського історичного мовознавства, зокрема, доповіді «3 історії українських юридичних термінів» (1961р.), «3 історії формування української термінології трудового права» (1966 р.) також показують історичний, міждисциплінарний науковий підхід науковця до предмета дослідження. Доповідь «Взаємини української та польської мов у процесі формування адміністративно-юридичної лексики другої половини X1Х ст.» (1982 р.) теж охоплює кілька розділів: історичне, порівняльне мовознавство, юридичну термінологію. 
До історичного мовознавства відносяться й статті з мовного франкознавства, одним словом лінгвофранкознавства. 3 цього розділу Олександра Антонівна написала, зокрема наукові доповіді «Вклад Івана Франка в розвиток української термінології» (1966р.), «Термінологічна лексика в епістолярні спадщині Івана Франка» (1971 р.), «Словник мови художніх творів Івана Франка (пробний зошит)» (1976 р.) та інші.

Три статті з лінгвошевченкознавства відносяться також до історичного мовознавства. До прикладу стаття «Комунікативна сила Шевченкового слова «дума»» (2015 p.).

Перша наукова публікація за темою кандидатської дисертації О.А.Сербенської «Про розроблення української юридичної термінології» (1958р.) була присвячена мовознавчому розділу - українське термінознавство, зокрема, підрозділу українська правнича термінологія, що свідчить про прикладний міждисциплінарний науковий підхід науковця до розуміння пріоритетних мовознавчих досліджень. До розділу правничої термінології також належить доповідь «Мова проекту «Кримінальний кодекс України» (1994р.), де йдеться про юридичну термінологію і лексику. Доповідь «Формування і розвиток української наукової термінології» (1992р.)

Статей з української термінології в доробку професора О.А.Сербенської - десятки. Так стаття «Про українські юридичні терміни «свідок», «сторона», «справа»» (1963 р.) відтворює результати досліджень окремих юридичних термінів. Дві опубліковані доповіді «Значення возз’єднання українських земель для уніфікації юридичної термінології української мови» та «Значення російської мови для формування українських складних і складених юридичних термінів» присвячені суспільно-політичним, історичним аспектам радянського періоду, чого вимагала й назва теми кандидатської дисертації «Розвиток української юридичної термінології після великої жовтневої соціалістичної революції». Окрім того, опубліковані статті О. А. Сербенської з термінознавства «Українські юридичні терміни для означення судових присудів», доповіді «Вклад Івана Франка в розвиток української термінології», «3 історії формування української термінології трудового права», «Дбаймо і про юридичну лексику», «Термінологічна лексика в епістолярній спадщині І.Франка», Функції терміна у газетному тексті», «Основні тенденції розвитку сучасної східнослов’янської юридичної термінології», «Юридична термінологія в мові творів Івана Франка (1962р.), статті «3 історії вивчення української юридичної термінології» (1963р.), «Значення російської мови для формування українських складних і складених юридичних термінів» (1964р.); «Українські юридичні терміни для означення судових присудів» (1966 р) ; «Вклад Івана Франка в розвиток української термінології» (1966 р.); доповіді «3 історії формування української термінології трудового права (1966 р.); «Українські терміни, зв’язані з веденням слідства (1969р.); «Термінологічна лексика в епістолярній спадщині І.Франка» (1971р.), «Мовні взаємини у процесі розвитку юридичної термінології російської та української мов» (1979р. ) та ін.

Мають місце в доробку Олександри Антонівни й статті з традиційних розділів теоретичного мовознавства - фонематики (вчення про звуки, звукові засоби української мови), статті з орфографії: «Проблеми українського правопису» (2001р.), а також з нових розділів: паралінгвістики, просодії, дериватології (словотворення), зокрема, стаття «Активні словотворчі процеси в мові сучасної преси» (1970р.). 
Проф. О.А.Сербенська досліджує в своїх статтях проблеми самостійних теоретичних мовознавчих дисциплін: фразеології (вчення про усталені звороти, ідіоми), Зокрема, це підтверджують статті з фразеології, іншими словами ідіоматики: «Фраземи в мові українського законодавства» (1972р.), «Трансформація фразеологічних одиниць у мові газети» (1978р.) «Використання фразеологізмів в епістолярному мовленні Івана Франка» (1983 р.) та інші.

Є серед публікацій О.А.Серебнської окремі статті з семасіології, ономатології, етимології. Але найбільше уваги О.А.Сербенська приділяє не теоретичній, а прикладній лінгвістиці, що дає право назвати її також прикладним лінгвістом, адже вона дбає про удосконалення українського правопису, україномовної вимови, дотримання культури української мови, словом бореться за екологію української мови.

О.А.Сербенська як науковець працює в галузі конкретного мовознавства, є конкретним мовознавцем, переважно об’єктом її досліджень є конкретна жива, текстова пресова, аудіо, аудіовізуальна українська мова.

Найдавніше Олександра Антонівна досліджує терміни, чим сприяє використанню уніфікованої юридичної термінології в правничій, журналістській сфері, що підтверджують зокрема, доповіді «Основні тенденції розвитку сучасної східнослов'янської юридичної термінології» (1974р.), «Науково-технічний термін у мові сучасної публіцистики» (1976р.), статті «Функції терміну в газетному тексті» (1976 р.), «Адаптація терміна: трансформації та інтерпретації media в українській мові (2015р.) Численні дослідницькі праці з термінології дають підстави назвати О.А.Сербенську ономатологом.

В науковому доробку О.А.Сербенської мають місце окремі статті $з$ діалектології, що присвячені живим говорам, діалектам. Зокрема, стаття «Взаємодія української літературної мови і діалектів у галузі юридичної лексики» (1972р.) .

Цікаві статті з лінгвогеографії, в яких дослідниця описує поширення певних рис мови на географічній території, її рідному Тернопіллі, Донецьку, Галичині, у Львові. До прикладу: доповіді «Характерні особливості мови преси Донбасу періоду перебудови» (1990р.), «Мова газет Тернопільщини», «Про мову Львова і про нас у слові. Рефлексії мовознавця» (2007 р.)

Укладанню словників, розділу лексикографіки, О.А.Сербенська присвятила десятки років. Цій тематиці належать їі наукові статті «Практичний словничок складних випадків слововживання» (2007 р., співавтор М. Білоус,); «Словник мови художніх творів Івана Франка» (2007); «Засади лексикографічного опрацювання медійної термінології в довіднику ,Słownik terminologii medialnej»»» (2006). Одноосібно й в співавторстві О.А.Сербенська підготувала видала 9 словників: «Практичний словничок складних випадків слововживання» (співавтор М. Білоус). «Словник паронімів української мови» (1986 р., 2008 р., співавтор - Д. Гринчишин) «Словник труднощів української мови» (1989р., співавтори:С. Срмоленко. Д. Гринчишин, О. Пазяк, 3. Терлак); «Словник-довідник з культури української мови» (1996р., співавтори: Д. Гринчишин, А. Капелюшний, 3. Терлак); «Практичний словничок нормативних висловів», 2002 р.; «Практичний словничок складних випадків слововживання» (2007 р., співавтори..); «Словник паронімів української мови» (1986 р., співавтор Д. Гринчишин); «Словник-довідник з культури української мови» (2006 р., співавтори: Д. Гринчишин, А. Капелюшний, 3. Терлак). 
Завдяки словникам, довідникам, що видані сотнями тисяч примірників, проф. О.А.Сербенська стала відомим українським лексикографом.

Працюючи над науково-дослідницькими темами щодо впровадження в комп'ютерні програми української мови, вивчення української мови за допомогою комп'ютера, викорінення деформацій української мови комп'ютером, проф. О.А.Сербенська вносить свій вагомий внесок як прагмалінгвіст в українське компі ютерне мовознавство. Цим питанням присвячені її статті: «Принципи розробки комп’ютерних програм з проблем культури української мови», «Наукові засади усунення деформацій української мови і його інформаційно-комп'ютерне забезпечення» та ін.

Водночас О.А.Сербенська є приписовим лінгвістом, розробляючи і рекомендуючи практичні норми української мови, особливо в роботі юристів, журналістів, користувачів комп’ютерами, вивчаючи функціонування української мови в різних ситуаціях професійного спілкування, особливо в ефірі аудіо-, аудіовізуального мовлення журналістів.

Відома Олександра Антонівна своїми науковими працями зі стилістики. До прикладу: доповідь «Уваги до стильових особливостей та правописної практики сучасних українських періодичних видань» (1997р.), стаття «Особливості стилю ділового мовлення I. Франка» (1985 р.), «Роль Івана Франка у становленні і розвитку публіцистичного стилю української мови» (1990р.).

Дослідниця Х.П.Дацишин слушно зауважує: «Олександра Сербенська у своїх працях переконливо доводить, що газетно-публіцистичне мовлення значною мірою зумовлене соціальними чинниками, воно відображає основні тенденції розвитку мови» [3; с.286]. Такі погляди пояснюють звернення професора О.А.Сербенської до соціолінгвістики в статтях: «Соціолінгвістичні засади Івана Франка» (2006р.), «Рідна мова як політичний прапор нації» (2006 р.), «Роль аудіовізуальних засобів у творенні звукового образу Держави» (2000 р.)

Працюючи на кафедрі телебачення й радіомовлення факультету журналістики ЛНУ ім. І. Франка, Олександра Антонівна займається прикладними дослідженнями, вивчає дотримання норм української літературної вимови в радіо-, телепередачах, розв'язує проблеми орфоепії радіо-, тележурналістики, що є підрозділами медіаорфоепії, в основі таких праць - унормування вимови українських слів у передачах радіомовлення, телебачення, про що йдеться в статті «Ефірне мовлення в контексті засад риторики» (2007р.) «Ефірне мовлення в соціокультурних та інформаційних вимірах» (2010 p.)

Висновки. Пріоритетні розділи мовознавчих досліджень професора О.А.Сербенської вражають актуальністю, новизною, затребуваністю, прикладним державой мовозахисним значенням.

Апостеріорі, випливає з дослідження іiї опублікованих мовознавчих праць, О.А.Сербенська своєю наполегливою працею не просто здійснила вагомий внесок у розвиток більшості розділів українського мовознавства: орфографію, орфоепію, пунктуацію, стилістику, термінологію, діалектологію, культуру української мови, дериватологію, та нові розділи прикладного мовознавства: лінгвоконцептологію, лінгвофеменологію, екологію української мови, екологію української мовної комунікації та інші.

O.А.Сербенська в автобіографічному нарисі «Часопростір мого буття» пише: «Робота на кафедрі радіомовлення і телебачення, де панує особливо сприятлива ат- 
мосфера для наукових пошуків (засновником кафедри і багаторічним ії керівником $€$ професор В. Лизанчук), дала мені змогу виділити ще одну важливу проблему - культуру нашого публічного мовлення, психолінгвістичні основи ефірного мовлення» [2]. Так Олександра Антонівна називає ще один новий розділ мовознавства мас-медіа: психолінгвістику ефірного мовлення, якому характерне комплексне поєднання розділів мовознавства з іншими науками (психологія, лінгвістика та прикладні галузі радіомовлення й телебачення) для всебічного, ефективного розв'язання проблем, що підтверджує наукову багатогранність, дає підстави вважати вельмишанованого ювіляра українським універсальним мовознавцем, а не лише термінознавцем, дослідником мови І.Франка, української культури мови, лінгвоекологом.

Найпершим пріоритетом мовознавчих досліджень професора О.А.Сербенської є орієнтири мовознавчих досліджень, спрямовані на захист державних інтересів. Пріоритетним прикладним напрямом науково-дослідницької діяльності проф. О.А.Сербенської з початку 90-х років і до нині є лінгвоекологія як захист і протистояння нівеченню української мови.

О.А.Сербенська є не тільки унікальним, універсальним мовознавцем, дослідником більшості традиційних і новітніх розділів мовознавства, а й фундатором львівської школи мас-медійних лінгвістів, під керівництвом якої захистили кандидатські дисертації І. Стецула, Л. Павлюк, Л. Конюхова, Х. Дацишин, О. Мітчук, Н. Лобур, В. Бабенко та ін.

Мовознавчі праці О.А.Сербенської мають і будуть мати вагоме значення для вдосконалення української писемної, розмовної мови, мови преси, радіомовлення, телебачення, розвитку українських Інтернет-3МІ, українського мовознавства загалом й утвердження української літературної мови в українській незалежній державі.

Подальші мовознавчі дослідження пріоритетів мовознавчих праць О.А.Сербенської - це вивчення пріоритетного поєднання мовознавчих розділів у виконаних науково-дослідницьких темах, що вперше в Україні реалізовували гострі прикладні мовні проблеми; дослідження пріоритетного поєднання мовознавчих галузей, розділів, підрозділів, дисциплін у наукових працях О.А.Сербенської; комплексне дослідження внеску у розвиток мовознавчих розділів у статтях, наукових доповідях, монографіях професора в контексті наукових пріоритетів.

\section{REFERENCES}

1. Олександра Сербенська / Упоряд. В.В. Лизанчук. Львів : ЛНУ імені Івана Франка, 2014. $232 \mathrm{c}$.

2. Сербенська O.A. Часопростір мого буття // http://archive.lnu.edu.ua/o-serbenskachasoprostir-moho-buttya/

3. Дацишин Х. Мовотворчість журналіста в науковій концепції Олександри Сербенської // Теле- та радіожурналістика. 2009. № 8. 


\title{
PRIORITIES OF LINGUISTIC RESEARCHES BY PROFESSOR OLEXANDRA SERBENSKA
}

\author{
Olena Kuznetsova \\ Lviv Polytechnic National University \\ 12 Bandera street, 79013, Lviv, Ukraine \\ e-mail: o.d.kuznetsova@gmail.com \\ https://orcid.org/0000-0002-9596-1386
}

The article analyzes scientific works: the articles, lectures on scientific conferences, dictionaries, monographs, scientific research themes of leading figure of Ukrainian linguistics professor of the chair of TV and radio of Lviv Ivan Franko national university Olexandra Antonivna Serbenska. It discovers her valued reference-points: service to all Ukrainian: to Ukrainian state, Ukrainian people, Ukrainian science, Ukrainian education; and also proves her priorities in scientific researches by chapters of applied Ukrainian linguistics, namely: philosophy of Ukrainian language, esthetics of Ukrainian language, history of Ukrainian language, comparativistics, Ukrainian-language «frankiana», derivatology. It also discovers the priority divisions of theoretical linguistics: lexicography, language ecology, language culture, onomatology, phraseology, ethimology, interdisciplinary combination of Ukrainian linguistics and theoretical journalism with other sciences and public spheres.

We see perspectives of the further research of scientific masterpiece of Olexandra Antonivna Serbenska in studying priorities of unification of linguistic chapters in researches already made which solved actual language problems - studying Ukrainian with the persona; computer, removing defects of Ukrainian language with computer, and also in exploring her priorities in unification of branches of applied linguistics, chapters, subchapters and disciplines in scientific works, complex research of her scientific contribution into modern didactics in context of scientific priorities.

Key words: Ukrainian theoretical, applied linguistics, culture of Ukrainian language, ecology of Ukrainian, terminology, phraseology, дериватологія, language франкознавство, new divisions of Ukrainian linguistics. 